\title{
Efficient Treatment of British Gas/Lurgi Coal Gasification Wastewater Using New Electro-Fenton Catalyzed by Biogas Residues and Coal Fly Ash Composite as Heterogeneous Catalyst
}

\author{
Lifeng Ping, Shengdao Shan, Haifeng Zhuang*, \\ Jianbo Guo, Chengran Fang
}

Key Laboratory of Recycling and Eco-treatment of Waste Biomass of Zhejiang Province, Zhejiang University of Science and Technology, Hangzhou, China

Received: 24 July 2017

Accepted: 1 October 2017

\begin{abstract}
Biogas residues and coal fly ash composite (CFA/BRC) were first investigated as novel heterogeneous catalysts for strengthening electro-Fenton (EF) of real British gas/Lurgi coal gasification wastewater. The prepared CFA/BRC was characterized by different techniques, i.e., SEM, XRD, BET surface area, XRF, and ICP-AES. The results indicated that CFA/BRC significantly improved performance of pollutant removal in $\mathrm{EF}$ across a wide $\mathrm{pH}$ range with current density of $10 \mathrm{~mA} / \mathrm{cm}^{2}$ and catalyst dosage of $1.0 \mathrm{~g} / \mathrm{L}$, and the treated wastewater was more biodegradable than homogeneous EF. Meanwhile, CFA/BRC showed superior stability at successive 2,400-min runs, and leached concentrations of heavy metals were very low without the second pollutant. The change of concentrations of dissolved oxygen and electro-generated $\mathrm{H}_{2} \mathrm{O}_{2}$, and fluorescence test indicated that the novel catalyst could enhance $\mathrm{H}_{2} \mathrm{O}_{2}$ decomposition into more hydroxyl radicals, which was considered to be mainly responsible for the pollutant removal. And the results offered new insights into sustainable use of waste materials.
\end{abstract}

Keywords: biogas residues, coal fly ash, British gas/Lurgi coal gasification wastewater, electro-Fenton, $\mathrm{H}_{2} \mathrm{O}_{2}$

\section{Introduction}

Coal gasification plays a key role in the strategy adjustment of energy structure in China due to the

*e-mail: Zhuanggao1984@163.com national energy characteristics of being "abundant in coal and poor in oil and gas" [1]. Particularly, the British gas/Lurgi (BGL) derived from Lurgi coal gasification has attracted massive attention and has been widely utilized because of its high production capacity and gas calorific value [2]. Badly, a substantial amount of BGL coal gasification wastewater (BGLCGW) containing a large number of toxic and refractory compounds is 
a high concentration of pollutants [3]. Accordingly, they are recalcitrantly degraded for conventional biological treatment, and the treated effluent cannot meet the increasingly stringent discharge standard, which poses a risk to aquatic organisms and humans [4]. Therefore, seeking out an efficient and cost-effective process for advanced treatment of BGLCGW is urgent and important, which has become a bottleneck for the development of the coal gasification industry in China.

In recent years, advanced oxidation processes (AOPs) have been widely used for the treatment of refractory wastewater, which can generate highly reactive intermediates (especially hydroxyl radical, $\bullet \mathrm{OH}$ ) to degrade recalcitrant organic pollutants [5-6]. Of all the available AOPs and the electro-Fenton (EF) process has attracted great attention, which utilizes electricity to insitu generation of $\mathrm{H}_{2} \mathrm{O}_{2}$ by oxygen reduction reaction on the cathode, being further enhanced by adding $\mathrm{Fe}^{2+}$ ions as a catalyst at pH of 2-4 [7]. Especially, the electroFenton integrated with the advantages of heterogeneous catalysts, i.e., a new heterogeneous electro-Fenton has been developed, which can be performed in a wide range of $\mathrm{pH}$ with high catalytic efficiency [8]. Ironbased materials, including iron oxides, iron organic complexes, and supporting carbon and so on [9] have been investigated to remove organic pollutants in catalyzed EF oxidation; however, the complicated preparation process and expensive or unavailable raw materials restrict its further development. Therefore, it is of great importance to prepare an efficient and stable heterogeneous catalyst suitable for full-scale application.

As one common low-grade biomass, biogas residues have emerged an urgent environmental issue in some agricultural regions that mainly consist of hemicellulose, lignin, and ash [10]. Compared with the fresh crop straws, its biogas residues after anaerobic digestion retained the main fibrous texture, which is essential for preparing activated carbon [11]. Meanwhile, coal fly ash (CFA) mainly consists of various metal oxides with higher content of iron oxides and thermal stability, which could provide cost-effective and environmentally friendly materials as metals active component of catalyst [12]. Therefore, it is a high expectation to integrate recycling biogas residues and CFA as the novel heterogeneous catalyst to enhance the performance of EF and additional economic benefits of waste. To the best of our knowledge, there is no study on using this type of heterogeneous catalyst to improve the performance of EF for treated real BGLCGW.

In the current study, biogas residues and CFA were recycled and converted into heterogeneous catalyst and the feasibility of strengthening on the EF treating real BGLCGW was investigated. The characteristics and catalytic activity of the heterogeneous catalyst was tested. Meanwhile, the advantages of applying the heterogeneous catalyst were discussed. Furthermore, a possible reaction mechanism was proposed and the results would offer new insights for sustainable use of waste materials.

\section{Materials and Methods}

\section{Materials}

The real British gas/Lurgi coal gasification wastewater used in this study was collected from the effluent of a secondary settling tank that had been pretreated by the anaerobic- and aerobic-activated sludge process in the full-scale wastewater treatment facility of a coal chemical plant in Erdos, China. The characteristics of wastewater were (in $\mathrm{mg} / \mathrm{L}$ ): COD of $170 \pm 20$, biochemical oxygen demand $\left(\mathrm{BOD}_{5}\right)$ of $8 \pm 1, \mathrm{BOD}_{5} / \mathrm{COD}$ ratio of $0.05 \pm 0.005$, total phenols of $90 \pm 10$, and $\mathrm{pH}$ of $6.5 \pm 0.2$. Biogas residues from an industrial-scale biogas plant using rice straws as main substrates were oven-dried at $105^{\circ} \mathrm{C}$ and then ground and homogenized to pass through a $100-\mu \mathrm{m}$ sieve. CFA was supplied by Donghua thermal power plant in Baotou City, China.

\section{Preparing the Catalyst}

Recycling biogas residues and CFA were applied for preparing catalysts by a one-step method combining the carbonization and activation of $\mathrm{ZnCl}_{2}$ [13]. First, the waste biogas residues and CFA and clay (as adhesive) with certain weight proportions of $60 \%, 35 \%$, and $5 \%$, respectively, were ground and sieved into a uniform size, and then the mixture samples were added into $3 \mathrm{~mol} / \mathrm{L}$ of $\mathrm{ZnCl}_{2}$ solution as activation agent (1:3, by mass) for stirring for $12 \mathrm{~h}$ at room temperature. When the supernatant liquid was completely removed, the sample was dried at $105^{\circ} \mathrm{C}$ and subsequently was pyrolyzed in a muffle furnace where high pure $\mathrm{N}_{2}$ was in-poured for producing the absence of oxygen condition. The furnace temperature was gradually increased at a rate of $20 \mathrm{~V} /$ min, and the final temperature of $550^{\circ} \mathrm{C}$ was maintained for $2 \mathrm{~h}$. The resulting samples were washed with Milli-Q water until the $\mathrm{pH}$ of rinsed water became constant, and was dried at $105^{\circ} \mathrm{C}$, which was designated as CFA/biogas residue carbon composite, i.e., CFA/BRC. Biogas residue carbon (BRC) was prepared using the same procedures but without adding CFA.

\section{Experimental Procedures}

EF reaction was conducted in a rectangular plexiglass reactor as a one-compartment electrochemical cell with effective volume of one $\mathrm{L}$ where the anode was a Pt sheet $(4 \times 5 \mathrm{~cm})$ and the cathode was a piece of activated carbon fiber with the same dimension and the gap between the electrodes was $5 \mathrm{~cm}$. The amount of catalyst (already adsorption for $24 \mathrm{~h}$ to ensure saturation) was first filled in-between the anode and cathode while switching on the DC current from a DC-stabilized power supply (MS155D), and the semicontinuous EF reaction was initiated. Continuous $\mathrm{O}_{2}$ saturation was provided by bubbling compressed air through a frit at $5 \mathrm{~L} / \mathrm{min}$, starting $10 \mathrm{~min}$ before reaction 
to reach a steady $\mathrm{O}_{2}$ concentration. In the adsorption test, without DC current, all other reaction conditions were kept identical. And the corresponding maximum adsorption of COD with BGLCGW were 25, 1.7, and $18 \mathrm{mg} / \mathrm{g}$ with $\mathrm{BRC}, \mathrm{CFA}$, and $\mathrm{CFA} / \mathrm{BRC}$, respectively, in $120 \mathrm{~min}$, the COD removal efficiencies were 13.8, 0.9, and $10 \%$, respectively, while the adsorption was close to saturation. Samples were withdrawn at pre-selected time intervals followed by heating for $1 \mathrm{~h}$ to remove excess $\mathrm{H}_{2} \mathrm{O}_{2}$ and filtered with a membrane $(0.45 \mu \mathrm{m}$, cellulose acetate). In the homogeneous EF process, $2 \mathrm{mmol} / \mathrm{L}$ of $\mathrm{Fe}^{2+}$ was used instead of CPE for catalyzing $\mathrm{H}_{2} \mathrm{O}_{2}$, and other reaction conditions were kept identical.

\section{Analytical Methods}

BET surface area and pore size distribution were determined using $\mathrm{N}_{2}$ adsorption-desorption experiments (Micromeritics ASAP 2020). X-ray fluorescence spectra (XRF) (Axios-pw4400, Holland) were applied to analyze the chemical elements composition (excluding $\mathrm{C}, \mathrm{H}$, and $\mathrm{N})$. The concentration of the dissolved metal ions in the catalyzed EF process was analyzed by ICP-AES (Optima 5300DU, Perkin Elmer Inc.). The morphology and structure of the prepared catalyst was examined with scanning electron microscopy (SEM, Phenom ProX, The Netherlands). The crystal structure was analyzed by a powder X-ray diffractometer (XRD, RigakuD/ max-2000) with monochromatic $\mathrm{Cu} \mathrm{Ka}$ radiation (45 $\mathrm{kV}, 50 \mathrm{~mA}$ ). The generation of $\bullet \mathrm{OH}$ was monitored by means of a terephthalic acid fluorescent probe method on an RF-6500 fluorescence spectrometer. COD and $\mathrm{BOD}_{5}$ were measured according to Standard Methods [14]. The organic compositions of BGLCGW and treated effluent were analyzed by gas chromatography and mass

Table 1. Summary of physicochemical properties of the catalysts.

\begin{tabular}{|c|c|c|c|}
\hline Parameters & BRC & CFA & CFA/BRC \\
\hline $\mathrm{S}_{\mathrm{BET}}\left(\mathrm{m}^{2} / \mathrm{g}\right)$ & 475.3 & 3.2 & 424.7 \\
\hline $\mathrm{V}_{\text {meso(macro })}\left(\mathrm{cm}^{3} / \mathrm{g}\right)$ & 0.352 & - & 0.317 \\
\hline $\mathrm{V}_{\text {micro }}\left(\mathrm{cm}^{3} / \mathrm{g}\right)$ & 0.217 & - & 0.191 \\
\hline Pore size $(\mathrm{nm})$ & 6.513 & - & 5.642 \\
\hline $\mathrm{Si}(\mathrm{wt} \%)$ & 5.22 & 21.71 & 10.73 \\
\hline $\mathrm{Al}(\mathrm{wt} \%)$ & 2.08 & 23.52 & 9.57 \\
\hline $\mathrm{Fe}(\mathrm{wt} \%)$ & 1.48 & 17.89 & 7.22 \\
\hline $\mathrm{Ca}(\mathrm{wt} \%)$ & 1.69 & & 1.01 \\
\hline $\mathrm{C}(\mathrm{wt} \%)$ & 35.87 & - & 38.49 \\
\hline $\mathrm{H}(\mathrm{wt} \%)$ & 4.17 & - & 2.15 \\
\hline $\mathrm{N}(\mathrm{wt} \%)$ & 1.55 & - & 1.23 \\
\hline $\mathrm{P}(\mathrm{wt} \%)$ & 6.52 & & 4.32 \\
\hline $\mathrm{K}(\mathrm{wt} \%)$ & 1.62 & & 1.17 \\
\hline
\end{tabular}

spectrometry according to the literature [15]. All the experiments were repeated three times, and the results are the average of at least three measurements with an accuracy of $\pm 5 \%$.

\section{Results and Discussion}

\section{Characteristics of the Prepared Catalyst}

As shown in Table 1, BRC and CFA/BRC all exhibit high specific surface area and the meso(macro)pores character, which was attributed to the etching function

a)

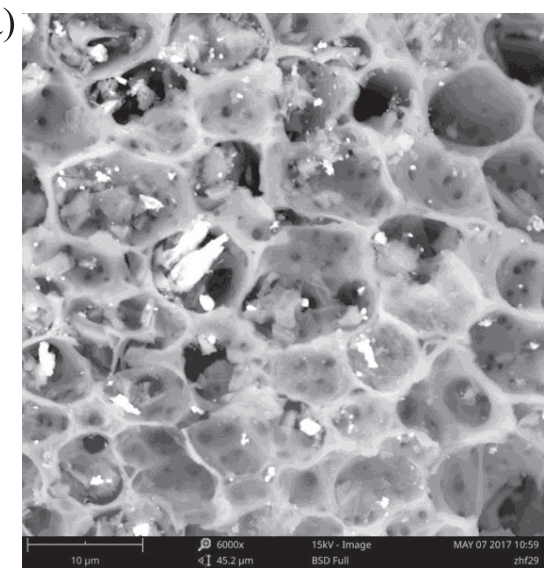

b)

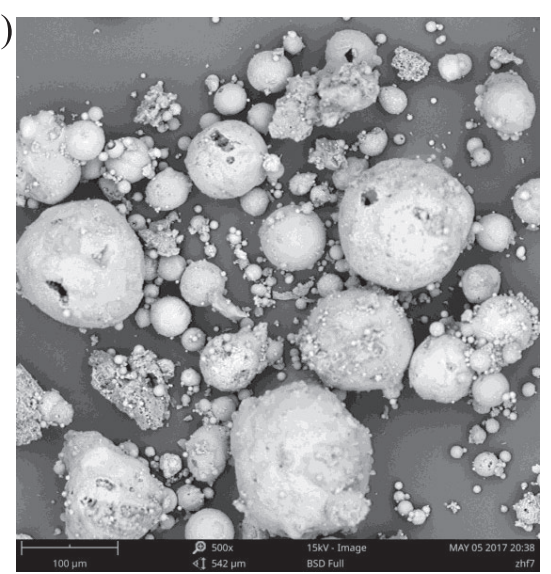

c)

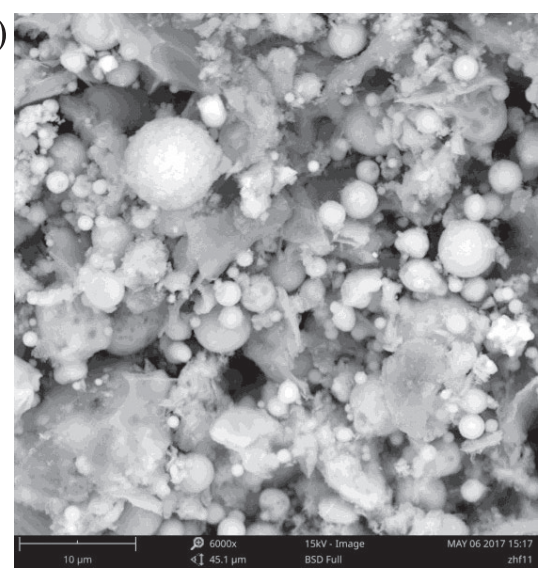

Fig. 1. SEM images of the catalysts: a) BRC, b) CFA, c) CFA/ BRC. 
Table 2. Leached concentrations of main metals of CFA/BRC in EF process at different $\mathrm{pH}(\mathrm{mg} / \mathrm{L})$.

\begin{tabular}{|c|c|c|c|c|c|c|}
\hline $\mathrm{pH}$ & $\mathrm{Si}$ & $\mathrm{Fe}$ & $\mathrm{Al}$ & $\mathrm{Cu}$ & $\mathrm{Cr}$ & $\mathrm{Pb}$ \\
\hline 4 & $1.98 \pm 0.6$ & $1.02 \pm 0.3$ & $1.83 \pm 0.7$ & $0.38 \pm 0.04$ & $0.09 \pm 0.01$ & $0.07 \pm 0.02$ \\
\hline 6 & $1.77 \pm 0.7$ & $0.95 \pm 0.2$ & $1.52 \pm 0.4$ & $0.25 \pm 0.03$ & $0.07 \pm 0.02$ & $0.06 \pm 0.02$ \\
\hline 8 & $1.55 \pm 0.5$ & $0.89 \pm 0.1$ & $1.21 \pm 0.3$ & $0.22 \pm 0.03$ & $0.06 \pm 0.01$ & $0.04 \pm 0.01$ \\
\hline Limits required in GB 18918-2002 & - & 10 & - & 0.5 & 0.1 & 0.1 \\
\hline
\end{tabular}

with the activation agent of $\mathrm{ZnCl}_{2}$ and the material nature. $\mathrm{C}, \mathrm{H}, \mathrm{N}, \mathrm{K}, \mathrm{Ca}, \mathrm{P}, \mathrm{Si}$, and $\mathrm{Al}$ were the main organic and inorganic components of biogas residues, which was attributed to their high cellulose, lignin, and hemicellulose contents that was suitable for preparing porous carbon-based materials during the pyrolysis process [16]. It was noteworthy that Fe content increased from $1.48 \%$ to $7.22 \%$ by adding CFA, which did not remarkably change the distribution of the pore diameter or specific surface area. The SEM images revealed that the surface morphology of BRC was uneven with welldeveloped porous structures, while the CFA with hollow cenospheres, mineral aggregates, and agglomerated particles was uniformly attached to BRC surface and embedded in a porous structure (Fig. 1), represented a well-dispersed mixture. Meanwhile, XRD patterns of CFA showed the peaks at $16.4^{\circ}$ and $26.2^{\circ}$, corresponding to mullite (alumino-silicate) phases, while quartz (silica) with strong peaks at $20.7^{\circ}, 26.6^{\circ}, 40.6^{\circ}$, and $49.9^{\circ}$ (Fig. 2). CFA/BRC exhibited a wide peak at $23.5^{\circ}$ corresponding to graphite carbon structure, especially the diffraction peaks at $30.5^{\circ}, 35.7^{\circ}, 44.2^{\circ}, 53.4^{\circ}$, and $62.3^{\circ}$ corresponding to the (220), (313), (400), (511), and (440) results that were in good line with that of $\gamma-\mathrm{Fe}_{2} \mathrm{O}_{3}$ (JCPDS 13-0534) or $\mathrm{Fe}_{3} \mathrm{O}_{4}$ (JCPDS 88-0866).

\section{Catalytic Activity}

The catalytic activity of the prepared catalyst on EF oxidation of real BGLCGW was investigated

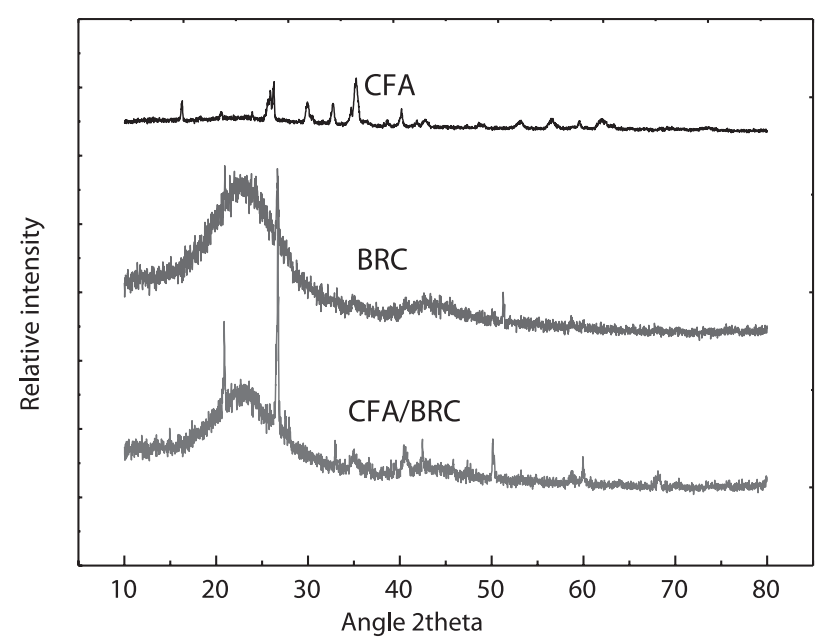

Fig. 2. XRD patterns of the catalysts.
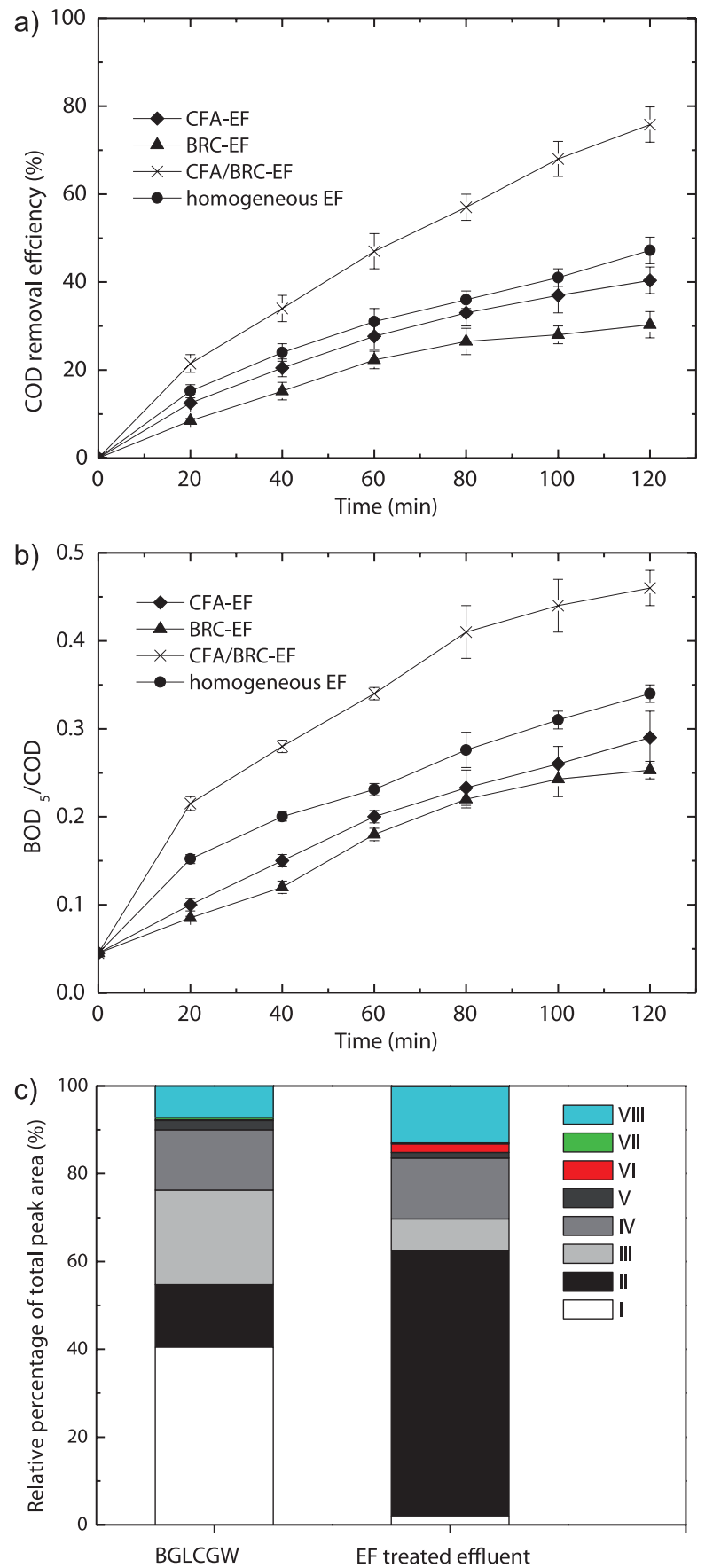

Fig. 3. Effects of catalysts on the performance of pollutant removal in the EF process: a) COD removal, b) $\mathrm{BOD}_{5} / \mathrm{COD}$, c) $\mathrm{GC}-\mathrm{MC}$ analysis (I, phenolic compounds; II, long-chain hydrocarbons; III, aromatic hydrocarbons; IV, olefin hydrocarbons; V, alcohols; VI, nitrogenous heterocyclic compounds; VII, polycyclic aromatic hydrocarbons; VII, others). 
under the raw wastewater $\mathrm{pH}$ condition with a dosage of one $\mathrm{g} / \mathrm{L}$ and current density of $10 \mathrm{~mA} /$ $\mathrm{cm}^{2}$. As shown in Fig. 3a), only $30.3 \%$ and $41.4 \%$ of COD was removed in EF with CFA and BRC, respectively, in $120 \mathrm{~min}$, while $47.2 \%$ of COD was degraded in homogeneous $\mathrm{EF}$ with added $2 \mathrm{mmol} / \mathrm{L}$ of $\mathrm{Fe}^{2+}$ as catalyst at $\mathrm{pH}$ 4. However, COD removal efficiency was dramatically increased in EF with $\mathrm{CFA} / \mathrm{BRC}$, and the final $75.8 \%$ of COD was removed, evidencing the wonderful catalytic activity of CFA/ BRC. The high removal efficiency was mostly due to the excellent characteristics of adsorption and catalysis of CFA/BRC, which can generate more $\mathrm{H}_{2} \mathrm{O}_{2}$ and powerful radicals during the electrochemical process.

The real BGLCGW contents amounts of toxic and refractory pollutants with poor biodegradability (about 0.05 of $\left.\mathrm{BOD}_{5} / \mathrm{COD}\right)$, which was difficult to break down with a biological process. Importantly, $\mathrm{BOD}_{5} / \mathrm{COD}$ was dramatically increased to $0.46,0.34,0.29$, and 0.25 for the CFA/BRC-EF, homogeneous EF, CFA, and BRCEF processes, respectively, which indicated that high toxic pollutants were removed and/or converted into less toxic or even non-toxic substances (Fig. 3b). The previous report had pointed out that the effluent was considered totally biodegradable as $\mathrm{BOD}_{5} / \mathrm{COD}$ higher than 0.4 , and only CFA/BRC-EF achieved this threshold
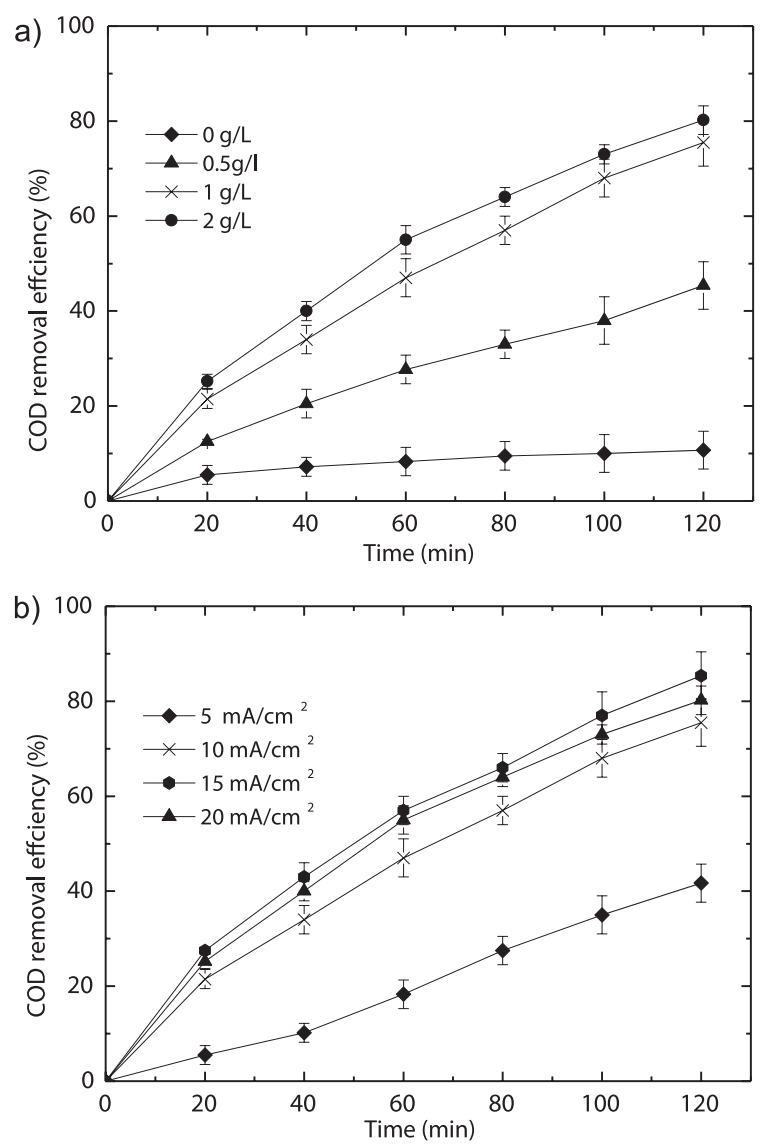

Fig. 4. Effect of operating parameters on treatment efficiency: a) CFA/BRC dosage, b) current density.
[17]. As shown in Fig. 3c), the residual ratio of toxic and refractory compounds in the treated effluent was significantly decreased, which was in accordance with better biodegradability. Finally, the main toxic and refractory compounds of the treated effluent were longchain hydrocarbons because of their stable hydrocarbon bonds being difficult to oxidize [17].

\section{Effects of Operational Parameters}

The effect of CFA/BRC dosage on the performance of EF oxidation of BGLCGW was examined by increasing amounts of CFA/BRC. As shown in Fig. 4a), while the dosage increased from 0.5 to one $\mathrm{g} / \mathrm{L}, \mathrm{COD}$ removal efficiency increased by $30.1 \%$, which was higher than that the dosage increase from one to $2 \mathrm{~g} / \mathrm{L}$. Anode oxidation only had $10.7 \%$ removal efficiency while without $\mathrm{CFA} / \mathrm{BRC}$. In fact, although greater amounts of CFA/BRC facilitated the improvement of treatment performance, excessive dosages would induce a short-circuit current in-between the anode and cathode that resulted in the reduction of current and removal efficiency [18], thus a dosage of $1.0 \mathrm{~g} / \mathrm{L}$ was reasonably selected.

The current density determines the formation of $\mathrm{H}_{2} \mathrm{O}_{2}$, which is an important parameter in the
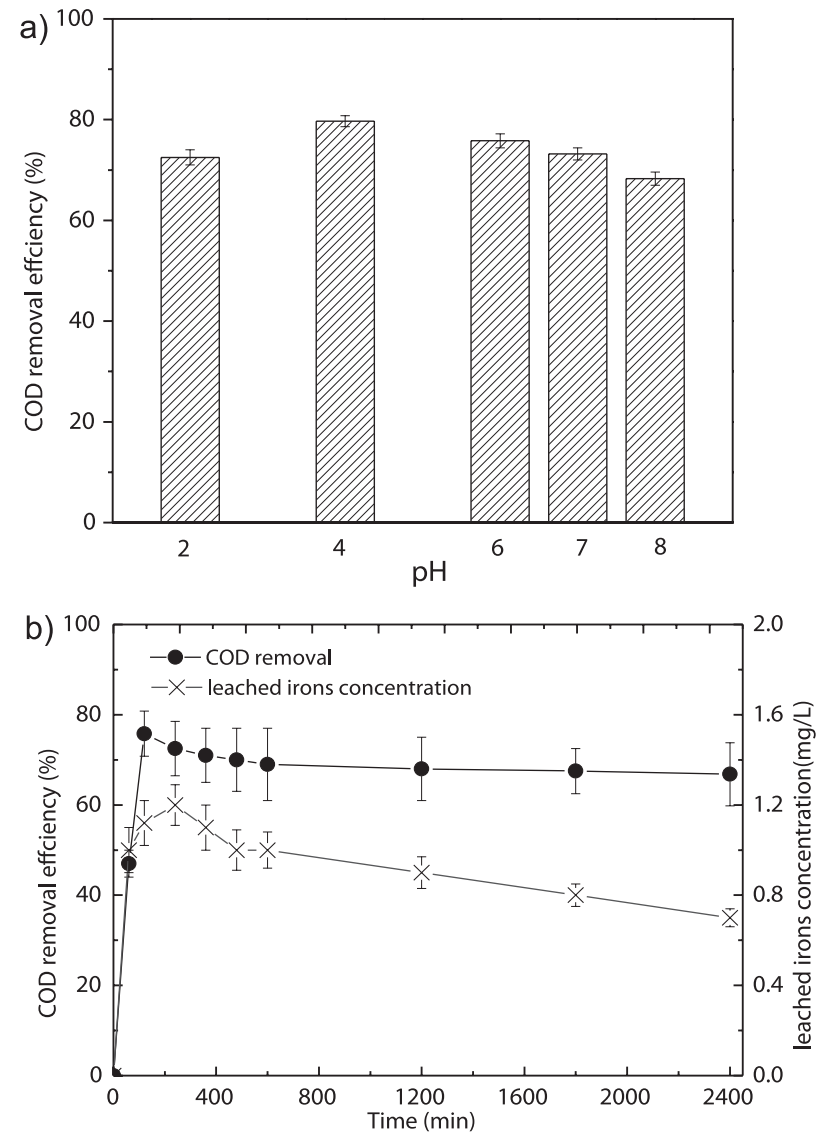

Fig. 5. Advantages in applying CFA/BRC in successive EF processes: a) effect of $\mathrm{pH}, \mathrm{b}$ ) stability. 
electro Fenton process. It was observed that at current density of $5 \mathrm{~mA} / \mathrm{cm}^{2}$, COD removal efficiency was only 41.7\% in CFA/BRC-EF after 120 min (Fig. 4b). But at $10 \mathrm{~mA} / \mathrm{cm}^{2}$, removal efficiency was improved to near $75.8 \%$, while that for $20 \mathrm{~mA} / \mathrm{cm}^{2}$ was only increased to $85.4 \%$. Exceeding high current density enhanced the occurrence of a side reaction and appeared to be scavenging radicals by excessive $\mathrm{H}_{2} \mathrm{O}_{2}$ In order to obtain excellent performance with low-energy cost, $10 \mathrm{~mA} / \mathrm{cm}^{2}$ was applied in the EF process.
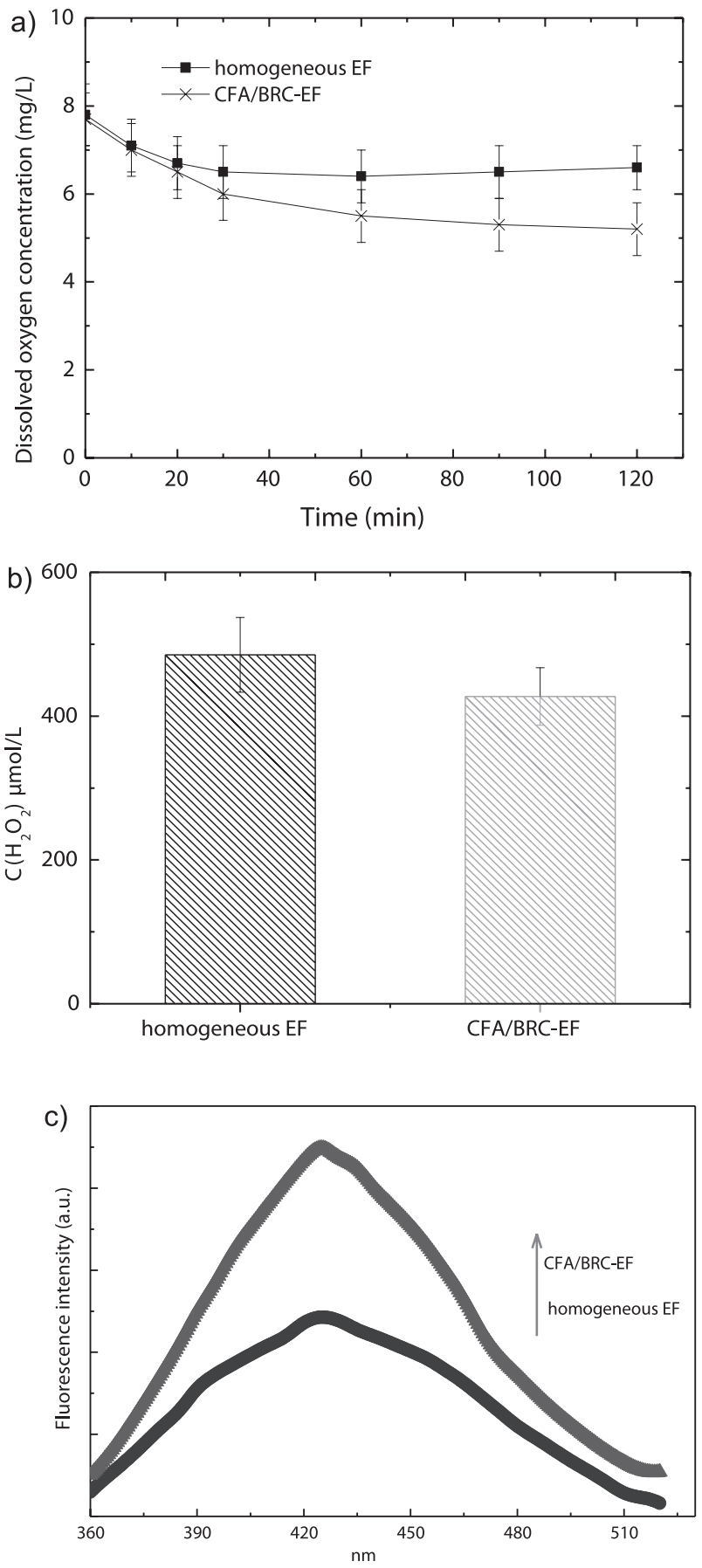

Fig. 6. $\mathrm{H}_{2} \mathrm{O}_{2}$ detection and fluorescence test for hydroxyl radical measurement.

\section{Advantages in Application}

The homogeneous electro-Fenton was sensitive to the higher $\mathrm{pH}$ value than 4 , which can be ascribed to the stability deterioration of $\mathrm{H}_{2} \mathrm{O}_{2}$ and the precipitation of ferric hydroxides with increasing alkalinity [19]. Fig. 5a) showed that the CFA/BRC had remarkable catalytic activity over a wide $\mathrm{pH}$ range, and that the decline of COD removal was not a significant change when $\mathrm{pH}$ increased from 2.0 to 8.0 after a 120 -min EF process. This might be ascribed to $\mathrm{H}_{2} \mathrm{O}_{2}$ being continuously electro-generated on the surface of CFA/BRC and the constant concentration being catalyzed by the active site, and the precipitation of iron never occurred. The raw wastewater $\mathrm{pH}$ was satisfactory, thus the operational costs associated with $\mathrm{pH}$ correction could be avoided.

Reusability of the catalyst is another critical parameter for the heterogeneous catalytic systems from an economic perspective, and the reusability of CFA/ $\mathrm{BRC}$ in EF oxidation was evaluated in Fig. 5b). No remarkable change was observed on catalytic activity at 2,400 min EF oxidation, and COD removal only decreased by $8.9 \%$ at the 20 th reuse, indicating that CFA/BRC recovery had good stability, which was attributed to its developed porous and iron-embedded structure. Meanwhile, the concentration of leached iron ions was around $1.0 \mathrm{mg} / \mathrm{L}$ in the cycles of reuse, lower than the amount of $2 \mathrm{mg} / \mathrm{L}$ in water for the European standard. As shown in Table 2, there were no remarkable differences in leaching of major metals of CFA/BRC while catalyzing the EF process when the $\mathrm{pH}$ increased from 4 to 8 , and the leached concentrations of main heavy metals in effluent were all lower than the discharge standard of pollutants for the municipal wastewater treatment plant (GB 18918-2002, China). The results showed that CFA/BRC had efficient and stable performance over a wide $\mathrm{pH}$ range in catalyzing $\mathrm{EF}$ oxidation of BGLCGW with low cost, eco-friendly, and sustainable developed advantages.

\section{Possible Reaction Mechanism}

Dissolved oxygen (DO) in the aqueous solution was mainly provided by aeration, which was a typical oxidant of electrons for electro-generated $\mathrm{H}_{2} \mathrm{O}_{2}$. Continuous aeration with $5 \mathrm{~L} / \mathrm{min}$ was applied to ensure reaching a steady $\mathrm{O}_{2}$ concentration starting $10 \mathrm{~min}$ before reaction, and the corresponding DO concentrations were $7.8 \mathrm{mg} / \mathrm{L}$ on average. Fig. 6a) indicated that DO concentration in solution rapidly reached equilibrium in homogeneous and CFA/BRC$\mathrm{EF}$ in the initial $30 \mathrm{~min}$. With the presence of the CFA/ BRC, the equilibrium DO concentration $(5.5 \mathrm{mg} / \mathrm{L})$ was much lower than that in homogeneous EF $(6.5 \mathrm{mg} / \mathrm{L})$, indicating the addition of the CFA/BRC significantly enhanced activate molecular oxygen to produce $\mathrm{O}^{2-}$ and subsequently generate $\mathrm{H}_{2} \mathrm{O}_{2}$. However, the corresponding amount of $\mathrm{H}_{2} \mathrm{O}_{2}$ was $427.4 \mathrm{mmol} / \mathrm{L}$ lower 
than homogeneous EF (Fig. 6b), which was probably attributed to the decomposition of $\mathrm{H}_{2} \mathrm{O}_{2}$ to more active - $\mathrm{OH}$ by the catalysis of CFA, since the detected amount was the equilibrium concentration of $\mathrm{H}_{2} \mathrm{O}_{2}$ [18]. A fluor photometer was used to estimate the possible role of - $\mathrm{OH}$ in various EF processes, and Fig. 6c showed that the quantity of $\cdot \mathrm{OH}$ was followed by the order $\mathrm{CFA} /$ $\mathrm{BRC}-\mathrm{EF}>$ homogeneous-EF, which was in accordance with the pollutants removal trend [20]. And the possible intervention of $\cdot \mathrm{OH}$ was considered to be mainly responsible for the pollutant removal in the catalyzed EF process. Thus, the results showed that EF with the CFA/BRC could remarkably improve the performance of pollutant removal and biodegradability at raw wastewater $\mathrm{pH}$ condition with stable, efficient, low-cost, and sustainable advantages, facilitating engineering applications and further catering to the concept of "using waste to treat waste."

\section{Conclusions}

Recycling biogas residues and coal fly ash as a heterogeneous catalyst significantly improved the performance of EF oxidation of real BGLCGW over a wide $\mathrm{pH}$ range with current density of $10 \mathrm{~mA} / \mathrm{cm}^{2}$ and catalyst dosage of $1.0 \mathrm{~g} / \mathrm{L}$, and the corresponding COD removal efficiency was $75.8 \%$. While the biodegradability of the treated wastewater was significantly improved with $\mathrm{BOD}_{5} / \mathrm{COD}$ increasing from 0.05 to 0.46 , the residual toxic and refractory compounds were significantly decreased. Meanwhile, CFA/BRC showed superior stability at successive 2,400-min runs. The change of concentrations of DO and electro-generated $\mathrm{H}_{2} \mathrm{O}_{2}$ and the fluorescence test indicated that the novel catalyst could enhance $\mathrm{H}_{2} \mathrm{O}_{2}$ decomposition into more $\cdot \mathrm{OH}$, which was considered to be mainly responsible for pollutant removal. Thus, CFA/BRC catalyzing EF oxidation could serve as an efficient, economical, and sustainable process with potential engineering applications for treated refractory wastewater.

\section{Acknowledgements}

This work was supported by the National Natural Science Foundation of China (No. 51708505) and Zhejiang Provincial Natural Science Foundation of China (No. LQ17E080008) and NSFC-Zhejiang Joint Fund for the Integration of Industrialization and Informatization (No. U1609214) and the Major Projects for Science and Technology Development of Zhejiang Province (No. 2017C03010).

\section{References}

1. WANG W., HAN H. Recovery strategies for tackling the impact of phenolic compounds in a UASB reactor treating coal gasification wastewater. Bioresour. Technol. 103 (1), 95, 2012.

2. ZHENG L.G., FURINSKY E. Comparison of Shell, Texaco, BGL and KRW gasifiers as part of IGCC plant computer simulations. Energ. Convers. Manage. 46, 1767, 2005.

3. ZHANG H.F., HAN H.J., SHAN S.D. Treatment of British Gas/Lurgi coal gasification wastewater using a novel integration of heterogeneous Fenton oxidation on coal fly ash/sewage sludge carbon composite and anaerobic biological process. Fuel. 178, 155, 2016.

4. LI P., AILIJIANG N., CAO X., LEI T., LIANG P., ZHANG X., HUANG X., TENG J. Pretreatment of coal gasification wastewater by adsorption using activated carbons and activated coke. Colloids. Surf. A. 482, 177, 2015.

5. OTURAN M.A., AARON J.J. Advanced oxidation processes in water/wastewater treatment: principles and applications: a review. Crit. Rev. Environ. Sci. Technol. 44, 2577, 2014.

6. ZHANG J., SHAO M.H., DONG H. Degradation of oil pollution in seawater by bipolar electro-Fenton process. Pol. J. Environ. Stud. 23, 933, 2014.

7. CRUA-RIZO A., GUTIERREZ-GRANADOS S., SALAZAR R., PERALTA-HERNANDEZ J.M. Application of electro-Fenton/BDD process for treating tannery wastewaters with industrial dyes. Sep. Purif. Technol. 172, 296, 2017.

8. HOU B.L., DENG R.J., ZHUANG H.F., YANG Y.B. Advanced treatment of coal chemical Industry wastewater by electro-catalysis with Gd-doped ti $/ \mathrm{SnO}_{2}$ Anode. Pol J. Environ. Stud. 26 (3), 1097, 2017.

9. ZHAO H., WANG Y., WANG Y., CAO T., ZHAO G. Electro-Fenton oxidation of pesticides with a novel $\mathrm{Fe}_{3} \mathrm{O}_{4}$ (a) $\mathrm{Fe}_{2} \mathrm{O}_{3}$ /activated carbon aerogel cathode: high activity, wide $\mathrm{pH}$ range and catalytic mechanism. Appl. Catal B-Environ. 125, 120, 2012.

10. CHEN Y., FENG Y.Z., WNEY S.S. Status and prospects of rural biogas development in China. Renewable Sustainable Energy Rev, 39, 679, 2014.

11. YANARDAG I.H., ZORNOZA R., CANO A.F., YANARDAG A.B., MEMUT A.R. Evaluation of carbon and nitrogen dynamics in different soil types amended with pig slurry, pig manure and its biochar by chemical and thermogravimetric analysis. Biol. Fertil. Soils. 51, 183, 2015.

12. WANG C.F., LI J.S., WANG L.J., SUN X.Y. Influence of $\mathrm{NaOH}$ concentrations on synthesis of pure-formzeolite A from fly ash using two-stagemethod. J. Hazard. Mater. 155, $58,2008$.

13. LIU C., TANG Z., CHEN Y., SU S., JIANG W. Characterization of mesoporous activated carbons prepared by pyrolysis of sewage sludge with pyrolusite. Bioresour. Technol. 101, 1097, 2010.

14. APHA, Standard Methods for the Examination of Water and Wastewater, $18^{\text {th }}$ ed. 1992, Washington, DC: American Public Health Association. 
15. ZHUANG H.F., HAN H.J., HOU B.L., JIA S.Y., ZHAO Q. Heterogeneous catalytic ozonation of biologically pretreated Lurgi coal gasification wastewater using sewage sludge based activated carbon supported manganese and ferric oxides as catalysts. Bioresour. Technol. 166, 178, 2014.

16. TANG Z., DENG Y.F., LUO T., XU Y.S., ZHU N.M., Enhanced removal of $\mathrm{Pb}(\mathrm{II})$ by supported nanoscale $\mathrm{Ni} / \mathrm{Fe}$ on hydrochar derived from biogas residues. Chem. Eng. J. 292, 224, 2016.

17. ZHUANG H.F., HAN H.J., JIA S.Y., HOU B.L., ZHAO Q. Advanced treatment of biologically pretreated coal gasification wastewater by a novel integration of heterogeneous catalytic ozonation and biological process. Bioresour. Technol. 166, 592, 2014.

18. HOU B.L., HAN H.J., JIA S.Y., ZHUANG H.F., XU P., LI K. Three-dimensional heterogeneous electro-Fenton oxidation of biologically pretreated coal gasification wastewater using sludge derived carbon as catalytic particle electrodes and catalyst. J. Taiwan. Inst. Chem. E. 60, 352, 2016.

19. WANG Y., ZHAO H., CHAI S., WANG Y., ZHAO G., LI D. Electrosorption enhanced electro-Fenton process for efficient mineralization of imidacloprid based on mixedvalence iron oxide composite cathode at neutral $\mathrm{pH}$. Chem. Eng. J. 223, 524, 2013.

20. HOU B.L., HAN H.J., ZHUANG H.F., XU P., JIA S.Y, Li $\mathrm{K}$. A novel integration of three-dimensional electro-Fenton and biological activated carbon and its application in the advanced treatment of biologically pretreated Lurgi coal gasification wastewater. Bioresour. Technol. 196, 721, 2015. 